\title{
PRICE-LEVEL ACCOUNTING, FULL DISCLOSURE, AND RULE 10b-5: HALF A LOAF IS NOT ALWAYS BETTER THAN NONE
}

\author{
Howard M. FRIEDMAN†
}

On December 31, 1974, the Financial Accounting Standards Board (FASB) proposed a major revision of generally accepted accounting principles. The Board, the body recognized as authoritative in the creation of accounting standards, ${ }^{1}$ issued an exposure draft entitled Financial Reporting in Units of General Purchasing Power. ${ }^{2}$ The document proposed that fiscal-year-end financial statements include supplemental restatements reflecting the current purchasing power of the dollar. ${ }^{3}$ Such reporting has generally been referred to as "price-level" accounting.

Although price-level accounting has been heralded as a substantial technical refinement, providing financial reporting with a constant unit of measurement, ${ }^{4}$ the approach may more realistically be seen as an attempt at pragmatic compromise between strong competing demands. On one hand are the desires to have

† Professor of Law, University of Toledo. B.A. 1962, Ohio State University; J.D. 1965, Harvard University; LL.M. 1967, Georgetown University. Member, Ohio Bar. The research for this Article was made possible by a Summer Faculty Fellowship of the University of Toledo.

${ }^{1}$ See 1 CCH APB Accounting Principles $\$ \S 510.08,520.01-.07$ (1973); SEC ACcounting Series Release No. 150, 5 CCH FED. SEc. L. REP. I 72,172 (Dec. 20, 1973); cf. Kripke, The SEC, The Accountants, Some Myths and Some Realities, 45 N.Y.U.L. REv. 1151, 1176-88 (1970). For a description of the FASB's procedures, see Armstrong, The Work and Workings of the Financial Accounting Standards Board, 29 Bus. LAw., March 1974, at 145 (special issue).

2 Financial accounting Standards Board, Financial Reporting in Units of General Purchasing Power (Exposure Draft, Dec. 31, 1974) [hereinafter cited as FASB EXPOSURE DRAFT].

${ }^{3}$ The original proposal would have required the new standards to apply to fiscal years beginning on or after Jan. 1, 1976. FASB EXPOSURE DRAFT, supra note 2, $\$ 57$. The Board, however, has delayed decision on adoption of the proposal until sometime this year. Wall St. J., Nov. 26, 1975, at 15, col. 1 .

${ }^{4}$ See Accounting Research Division Staff, AICPA, Reporting the Financial Effects of Price-Level Changes 24-27 (Accounting Research Study No. 6, 1963) [hereinafter cited as ARS No. 6]. 
financial statements reflect current values of assets ${ }^{5}$ and to have income for at least some purposes reflect charges based on replacement costs of assets. ${ }^{6}$ On the other hand is the need to have accounting principles that deter management manipulation of asset and earnings figures. ${ }^{7}$

A reaction to the investor losses of the Great Depression was insistence upon use of historical cost in financial statements ${ }^{8}$ and the requirement that no gains or losses be recognized until realized by actual sale or some similarly objective measure. ${ }^{9}$ These principles of accounting substantially lessened the possibility of puffing in financial statements, generally eliminating write-ups of assets based on inaccurate appraisals. At the same time, the increasing importance of income figures for investors shifted attention away from the balance sheet, which no longer reflected figures of much economic significance, and focused attention on the income statement. ${ }^{10}$

But during periods of constantly spiraling inflation, income statement figures based on historical costs also rapidly become obsolete. So long as obsolescence was primarily confined to the depreciation figure, management showed little concern. ${ }^{11}$ This

${ }^{5}$ See Edwards, The State of Current Value Accounting, 50 Accounting Rev. 235 (1975).

6 Management's desire to reflect higher replacement costs, and thus show lower income, is usually directed toward attempts to reduce income tax burdens. For this reason, INT. REv. CoDE of 1954, § 472(c), required that if last in, first out inventory valuation is to be used for tax purposes, it must also be used for reporting to shareholders and for credit purposes. Cf. Kripke, supra note 1, at 1189-90.

"More precisely, this should be described as a concern for "objectivity" in the presentation of accounting data. See M. Moonitz, The Basic Postulates of Accounting 42-43 (Accounting Research Study No. 1, 1961).

${ }^{8}$ See Kripke, supra note 1 , at $1188-89$.

${ }^{9}$ Cf. Arnett, What Does "Objectivity" Mean to Accountants?, $111 \mathrm{~J}$. Accountancy, May 1961 , at 63 .

${ }^{10}[\mathrm{~T}]$ he problems in the field of accounting have increasingly come to be considered from the standpoint of the buyer or seller of an interest in an enterprise, with consequent increased recognition of the significance of the income statement . . . . With the increasing importance of the income statement there has been a tendency to regard the balance sheet as the connecting link between successive income statements....

Restatement and Revision of Accounting Research Bulletins $₫ 3,2 \mathrm{CCH}$ APB Accounting Principles 6005 (Accounting Research Bulletin No. 43, 1953) [hereinafter cited as ARB No. 43]. See also Hayes, Accounting Principles and Investment Analysis, $30 \mathrm{~L}$. \& Contemp. Prob. 752, 768 (1965); Graham, Some Observations on the Nature of Income, Generally Accepted Accounting Principles, and Financial Reporting, 30 L. \& CoNTEMP. Prob. 652, 661-64 (1965). For an important discussion of the history, purposes, and future of financial accounting, see Kripke, $A$ Search for a Meaningful Securities Disclosure Policy, 31 Bus. LAw. 293 (1975).

${ }^{11}$ In the Preface to its Exposure Draft, the FASB states: "Despite a 1969 recommen- 
lack of interest may be explained in part by the fact that traditional depreciation accounting does roughly compensate for increases in replacement costs. The failure to account for the gap between depreciation reserves and replacement cost is offset by the failure to recognize imputed income from interest-free use of those reserves over the life of the depreciable asset. ${ }^{12}$ The impact of rapidly rising prices became more apparent, however, when, with pricing based on replacement cost and accounting of cost of goods sold based on a first in, first out method, ${ }^{13}$ earnings surged with "inventory" profits. Often profit levels would quickly fall to more normal levels in subsequent periods when statements would reflect substantially higher costs of goods sold. ${ }^{14}$ The first reaction to this distortion was a rush by companies to change from FIFO to LIFO accounting for inventories. ${ }^{15}$ The impact of inflation on income, however, extends beyond inventory problems. For example, interest rates on longterm borrowing have risen dramatically to reflect the cheaper dollars that are used in repayment. ${ }^{16}$ But as fixed asset costs rise even faster than interest rates the relationship between depreciation reserves and replacement costs has become so attenuated as to lose all validity. As early as 1947, the accounting profession recognized this serious impact on accounting for productive facilities: "Stockholders, employees, and the general public should be informed that a business must be able to retain out of profits amounts sufficient to replace productive facilities at current prices if it is to stay in business."17

Thus, rapid price increases, particularly in 1974, led to the dusting-off of more general proposals to deal with monetary

dation of the Accounting Principles Board, few enterprises in the United States have reported financial information expressed in units of general purchasing power . . .." FASB EXPosure DRAFT, supra note 2, at iii.

${ }^{12}$ See W. Paton, Essentials of Accounting 534-35 (1938); Blum \& Katz, Depreciation and Enterprise Valuation, 32 U. CHI. L. REv. 236 (1965).

${ }^{13}$ For a description of first in, first out (FIFO) and last in, first out (LIFO) inventory accounting see W. Meigs, C. Johnson, T. Keller \& A. Mosich, Intermediate Accounting 257-61 (2d ed. 1968).

${ }^{14}$ See Bastable \& Merriwether, Fifo in an Inflationary Environment, $139 \mathrm{~J}$. Accountancy, March 1975, at 49.

${ }^{15}$ See, e.g., Wall St. J., Jan. 10, 1975, at 6, col. 3.

${ }^{16}$ See Sommer, Inflation May Keep Interest Rates Up, IND. WEEK, July 1, 1974, at 45. See also Hendershott \& Van Horne, Expected Inflation Implied by Capital Market Rates, 28 J. Fin. 301 (1973).

${ }^{17}$ Letter from the Committee on Accounting Procedure, American Institute of Certified Public Accountants, to the profession, Oct. 14, 1948, reproduced at ARB No. 43 , supra note 10 , at ch. 9a, I 17. 
inflation. These earlier proposals had surfaced in every inflationary period since World War II. ${ }^{18}$ The FASB's new proposal, however, has a dramatic new aspect-price-level adjustments in supplemental statements would be mandatory for all businesses that desire to have their financial statements certified as in accordance with generally accepted accounting principles. ${ }^{19}$

The FASB proposal's response to inflation is not the only one possible. An alternative is to adjust asset figures to reflect specific price changes rather than indexes of general inflation. This adjustment may employ either the current replacement cost (the cost of new assets of equal productive capacity) or the current value (the price of reproducing the existing assets in identical form). ${ }^{20}$ On August 21, 1975, the Securities and Exchange Commission proposed amendments to its accounting rules, regulation $\mathrm{S}-\mathrm{X},{ }^{21}$ to require inclusion of certain current replacement cost figures in financial statements. Footnotes would provide these data for inventories and depreciable assets comprising the productive capacity of the firm. ${ }^{22}$ As this Article suggests, a current value or cost approach offers a much better possibility of

\footnotetext{
${ }^{18}$ For a review of these proposals, see FASB EXPosure DRAFT, supra note 2, กI 58-63.

${ }^{19}$ Id. If 31

${ }^{20}$ The basic objective of the Commission in proposing to require replacement cost data is to give investors information about the current economics of business operations rather than the value of business assets. The disclosures proposed do not represent a current value approach, although presumably assets measured by current cost will more closely approximate current value than will historical cost data.
}

SEC Securities Act Release No. 5608, [Current] CCH FED. SEC. L. REP. đ 80,270, at 85,579 (Aug. 21, 1975) [hereinafter cited as SEC Securities Act Release No. 5608]. For the SEC proposal, see note 22 infra \& accompanying text.

${ }^{21} 17$ C.F.R. pt. 210 (1975).

${ }^{22}$ SEC Securities Act Release No. 5608, supra note 20. Final SEC staff recommendations on the proposals are to be submitted to the Commission by May 1, 1976. Address by SEC Chairman Roderick M. Hills, AICPA Conference, Washington, D.C., Jan. 7, 1976, reproduced in BNA SEC. REG. \& L. REP. No. 335 at E-l (Jan. 14, 1975). The proposal would require financial statements filed with the SEC to include in footnotes: (1) the current replacement cost of inventories; (2) the cost effect of sales during the past two years if costs current at the times of sales had been used; (3) the current cost of replacing productive capacity together with current net replacement cost represented by the depreciable, depletable, and amortizable assets; (4) depreciation, depletion, and amortization for the past two years based on current replacement cost; (5) the methods used in determining the above amounts; and (6) any other information necessary to prevent the above information from being misleading (e.g., historical relationships between cost changes and selling price changes, difficulties in replacing productive capacity).

The SEC's proposal calls for the use of replacement cost, the amount necessary to obtain equivalent operating or productive capacity, not cost of reproducing the existing assets in identical form. 
accurately reflecting information investors wish to know ${ }^{23}$ than does the FASB proposal.

General price-level adjustment proposals, such as the FASB's, are a reaction to the primary difficulty with current cost and value accounting - the lack of objective measures in many instances. ${ }^{24}$ The spectre of fraudulent and excessive appraisals of assets continues to haunt the accounting profession. The use of general price level adjustments avoids this problem by focusing upon a method of adjustment of values that is completely beyond manipulation by individual enterprises. This method is the adjustment of financial statements to reflect not actual current costs or values, but rather the overall change in the purchasing power of the dollar. ${ }^{25}$ Use of government-supplied indexes unrelated to specific commodities provides an "objective" test of decreases in the purchasing power of the dollar. ${ }^{26}$ And that test fits into a perfectly logical academic model of economic reporting, one that measures results in terms of constant dollars.

The problem with the FASB proposal is that it yields a series of financial statistics incomprehensible to the average investor. ${ }^{27}$ This mass of information, even if understood by the average investor, is unlikely to be seen as helpful. ${ }^{28}$ The accounting profession's half-step toward current value accounting may not be better than none. Price-level accounting is a trap for the unwary and it is the unwary, the unsophisticated investor, to whom the minimum required disclosure must be comprehensible under current legal standards. ${ }^{29}$

${ }^{23} \mathrm{~A}$ current cost approach has been adopted in the United Kingdom for periods beginning after Dec. 24, 1977. Wall St. J., Nov. 28, 1975, at 15, col. 4.

${ }^{24}$ For an attempt by the SEC to deal with potential liability on the part of persons exercising judgment in making financial disclosures, see proposed rule 132 under the Securities Act of 1933 and proposed rule 3b-6 under the Securities Exchange Act of 1934. Securities Act Release No. 5581, [1974-1975 Transfer Binder] CCH FED. SEc. L. REP. If 80,167 (Apr. 28, 1975) (liability for misleading projections of future revenues, sales, net income, or earnings per share).

${ }^{25}$ For a review of the historical development of asset valuation procedures, see $M$. Chatfield, A History of Accounting Thought $231-53$ (1974).

${ }^{26}$ See Tierney, The Index Number Problem, in ARS No. 6, supra note 4, at 57-117.

${ }^{27}$ Even current annual reports of corporations are largely not understood by the small stockholder. See Georgeson \& Co., New Trends in AnNual Report Readership 4 (1972); note 119 infra \& accompanying text.

${ }^{28}$ Note 105 infra \& accompanying text.

${ }^{29}$ Although a widely quoted opinion states that shareholders need not be addressed "as if they were children in kindergarten," Richland v. Crandall, 262 F. Supp. 538, 554 (S.D.N.Y. 1967), the average reasonable investor as well as the securities professional must be able to understand the required disclosures. See Feit v. Leasco Data Processing Equip. Corp., 332 F. Supp. 544, 565-66 (S.D.N.Y. 1971). See also Panel Discussion, New 
From the lawyer's point of view, the FASB proposal raises the question of how much deference the SEG and the courts should show toward principles propounded by the accounting profession $^{30}$ when determining whether particular disclosures conflict with rule $10 \mathrm{~b}-5^{31}$ Although generally accepted accounting principles have significant weight with the SEC,32 adherence to these principles does not necessarily meet the required standards of disclosures. ${ }^{33}$

The prime utility of the FASB proposal is to encourage reforms that will reduce the federal income tax burden in times of inflation. ${ }^{34}$ But presenting the information as part of financial statements disseminated to investors could violate the standards for disclosure developed under rule 10b-5. The explanations required by the exposure $\mathrm{draft}^{35}$ may not be sufficient to avoid misleading implications. Sufficient disclosure may be impossible ${ }^{36}$ or so cumbersome and costly as to make price-level accounting an inordinate drain on corporate resources in light of the purposes the proposal will in fact serve. ${ }^{37}$

The proposal may actually mandate the wrong disclosure.

Approaches to Disclosure in Registered Security Offerings, 28 Bus. LAw. 505, 527-28 (1973) (remarks of Harold Marsh, Jr.).

${ }^{30}$ See notes 32-33 infra \& accompanying text.

3117 C.F.R. $\$ 240.10 b-5$ (1975):

It shall be unlawful for any person, directly or indirectly, by the use of any means or instrumentality of interestate [sic] commerce, or of the mails or of any facility of any national securities exchange,

(a) To employ any device, scheme, or artifice to defraud,

(b) To make any untrue statement of a material fact or to omit to state a material fact necessary in order to make the statements made, in the light of the circumstances under which they were made, not misleading, or

(c) To engage in any act, practice, or course of business which operates or would operate as a fraud or deceit upon any person, in connection with the purchase or sale of any security.

32 SEC Accounting Series Release No. 150, 5 CCH FED. SEC. L. REP. I 72,172 (Dec. $20,1973)$ [hereinafter cited as ASR No. 150].

${ }^{33}$ United States v. Simon, 425 F.2d 796 (2d Cir. 1969), cert. denied, 397 U.S. 1006 (1970); Kaiser-Frazer Corp. v. Otis \& Co., 195 F.2d 838 (2d Cir.), cert. denied, 344 U.S. 856 (1952); Herzfeld v. Laventhol, Krekstein, Horwath \& Horwath, 378 F. Supp. 112 (S.D.N.Y. 1974).

${ }^{34}$ The tax aspects of the proposal are discussed at notes 155-63 infra.

${ }^{35}$ See FASB EXPosure DraFT, supra note 2, If 56.

${ }^{36} \mathrm{Cf}$. Jerry W. Smith, [1972-1973 Transfer Binder] CCH Fed. SEc. L. ReP. If 78,856 (SEC staff letter, May 16, 1972); Ferris \& Co., [1972-1973 Transfer Binder] CCH FED. SEC. L. REP. $\{78,903$ (SEC staff letter, Apirl 24, 1972) (finding no amount of disclosure would remove the potential for deception in limited publication of the performance of hypothetical accounts kept by investment advisers under the Investment Advisers Act rules).

${ }^{37}$ See notes $155-63$ infra \& accompanying text. 
Once an issuer leaves the SEC accepted-as well as generally accepted-accounting practice of using historical costs, present value or replacement cost may surface as a material fact for investors and may become the only safe harbor for accounting practice.

\section{The FASB Proposal}

At the heart of the FASB proposal is a reexamination of the traditional role of the dollar as a measuring unit in financial statements. In measuring assets, liabilities, and changes in assets and liabilities, accounting principles have assumed that the dollar is a constant unit of measure, while, in fact, dollars from different years reflect different amounts of purchasing power. ${ }^{38}$ Thus, figures that are composites of transactions for different years include dollars of varying values. The FASB proposal would convert all financial statement figures to dollars of equal purchasing power. Under the proposal current dollars, those as of the date of the annual balance sheet, would be the common unit of measurement. ${ }^{39}$

The FASB has chosen to use the Gross National Product Implicit Price Deflator to determine the purchasing power of the dollar. ${ }^{40}$ This index, compiled by the Bureau of Economic Analysis of the Department of Commerce, is the most comprehensive index of prices in the United States. It includes all goods and services, not merely those in a particular segment of the economy. Thus it is a better measure of general purchasing power of the dollar than such better known indexes as the Consumer Price Index and the Wholesale Price Index. ${ }^{41}$ The GNP Implicit Price Deflator equates 1958 dollars to an index number of 100. By the fourth quarter of 1965 the index stood at 111.5. By the third quarter of 1975 , it had risen to $186.0 .^{42}$

Unlike proposals that suggest adjustment of only certain items in financial statements, such as depreciation, ${ }^{43}$ the FASB

${ }^{38}$ See Accounting Principles Board, Basic Concepts and Accounting Principles Underlying Financial Statements of Business Enterprises ๆf 165-68, 2 CCH APB Accounting Principles 9088 (APA Statement No. 4, 1970).

${ }^{39}$ FASB Exposure Draft, supra note 2, ๆ 36.

${ }^{40} \mathrm{Id}$. If 35.

41 For a comprehensive discussion of indexes, see Tierney, supra note 26.

${ }^{42}$ GNP Deflators beginning in 1929 are collected in FASB Exposure DRAFT, supra note 2, at 34-35. Recent figures through the third quarter of 1975, as revised, may be found in U.S. Dep'T of Commerce, 55 Survey of CurRent Business, Nov. 1975, at S-2.

${ }^{43}$ See FASB EXPosure Draft, supra note 2, 9 73. See also ARS No. 6, supra note 4, at 54-55. Examples of partial adjustments are contained in id. 211-18. 
proposal contemplates restatement of all figures in both balance sheet and income statement. ${ }^{44}$ Although the Exposure Draft permits less than a completely restated set of financial statements, the items that are required entail virtually complete restatements in working papers in order accurately to reflect required disclosures. The income statement must show the following in general purchasing power units: revenues, depreciation, net gain or loss from holding monetary liabilities or assets, net income in total and per share, and cash dividends per share. ${ }^{45}$ The restated balance sheet must show: inventories; working capital; total property, plant, and equipment, net of depreciation; total assets; and common shareholders' equity. ${ }^{46}$

The proposal can best be understood by reconstructing several figures from a set of financial statements to reflect pricelevel adjustments. Assume Acme Widget Co. was formed on January 1,1970 , at which time it purchased land costing $\$ 10,000$ and a building with a thirty year anticipated life costing $\$ 90,000$. On a traditional balance sheet, assuming straight-line depreciation and no salvage value for the building, these items would appear as follows as of the end of 1974:

Land

Building

Less: Depreciation

$$
\begin{array}{ll}
90,000 & \$ 10,000 \\
15,000 & \\
& 75,000
\end{array}
$$

Restated in terms of 1974 fourth quarter dollars, they would appear as follows:

Land

Building

Less: Depreciation
120,542

20,090
$\$ 13,394$

100,452

These price-level adjusted figures are reached by multiplying historical figures by:

$$
\frac{178.0}{132.9} \text { (GNP Deflator, Fourth Quarter 1974) }
$$

This fraction represents the relation between current dollars and dollars at the time the items were acquired. For assets acquired

\footnotetext{
${ }^{44}$ FASB Exposure Draft, supra note 2, II 33, 73.

${ }^{45}$ Id. I 54.

${ }^{46}$ Id. ปी $54-55$.
} 
in other quarters the denominator would be the Gross National Product Deflator for the quarter of acquisition. Similar restatements would be made for other "nonmonetary" 47 items.

Certain items, however, by law or contract represent a claim on a fixed number of dollars, regardless of changes in purchasing power. These items, such as cash, fixed-dollar receivables and fixed-dollar liabilities, are not restated. Such items, labeled "monetary" items by the FASB, instead result in gains or losses to the holder during periods of price change. ${ }^{48}$ The company that holds cash during inflationary periods effectively suffers losses in purchasing power. On the other hand, holding monetary liabilities results in gains because the debts will be repaid in "cheaper" dollars.

Under the FASB proposal, gains and losses from holding of monetary items are recognized in the year of the price change. ${ }^{49}$ Thus, suppose Acme Widget held $\$ 50,000$ in cash throughout 1974 . It thereby suffers a purchasing power loss of $\$ 6,010$ computed as follows:

$$
\begin{aligned}
& \frac{178.0^{\mathrm{a}}}{158.9^{\mathrm{b}}} \times 50,000=56,010^{\mathrm{c}} \\
& 56,010-50,000=6,010^{\mathrm{d}} \\
& \hline \text { a (GNP Deflator, Fourth Quarter 1974) } \\
& \text { b (GNP Deflator, Fourth Quarter 1973) } \\
& \text { c (Amount in end of year dollars) } \\
& \text { d (Loss) }
\end{aligned}
$$

Holding of debt results in comparable gain. Thus, the company that is in a net liability position as to monetary items during a period of inflation will experience purchasing power gains during the period. Purchasing power gains or losses, appearing in

${ }^{47}$ For a detailed classification of "monetary" and "nonmonetary" items, see id. $\uparrow 85$.

${ }^{48}$ See ARS No. 6, supra note 4, at 135-65.

${ }^{49}$ FASB EXPosure DrafT, supra note 2, If 48. Some accountants have suggested that gain on long-term debt (a monetary item) used to finance depreciable assets ought to be recognized not in the year of general price level changes, but rather should be spread over the life of the asset. The larger dollar amount of depreciation created by price level adjustments would thus be reduced by offsetting against it the gains arising from financing the purchase of assets rather than paying cash. See, e.g., Deupree, $A c-$ counting for Gains and Losses in Purchasing Power of Monetary Items, in ARS No. 6, supra note 4, at 153. The FASB has rejected this approach. See generally ARS No. 6, supra, 41-42; Accounting Principles Board, Financial. Statements Restated for General Price-Level Changes If 41-42, 2 CCH APB Accounting Principles 9015 (APB Statement No. 3, 1969). 
the restated income statement as a separate item, reflect the results of holding such monetary items each year.

Finally, these changes, of course, affect stockholders' equity accounts. Under the FASB proposal, preferred stock "that is carried in the balance sheet at an amount equal to its fixed liquidation or redemption price" 50 is classified as a monetary item, that is, as a liability of fixed amount owed to holders. Changes in purchasing power therefore affect almost exclusively the common stockholders' equity. ${ }^{51}$

The FASB proposal assumes that gains inuring to common shareholders should be reflected proportionately in all the common stock accounts: capital stock, additional paid-in capital, and retained earnings. Because restating each account separately would involve the complexity of determining the date on which each component of each account arose, the proposal finds it sufficient to use a residual approach that aggregates all the common stockholders' equity accounts in a single figure. ${ }^{52}$

The FASB proposal contemplates that comparative figures for two or more years will also be adjusted for price-level changes. ${ }^{53}$ At the end of 1974, when Acme Widget wishes to include in its annual report to shareholders comparative balance sheets and income statements for 1973 and 1974, all figures that had been entered in the 1973 statements in December 1973 dollars are "rolled forward" to December 1974 dollars. Even monetary items are restated solely for purposes of comparison. If Acme held $\$ 50,000$ in cash at the end of 1973 , at the end of 1974 this is restated on the 1973 balance sheet at $\$ 56,010$ in 1974 dollars. Thus if cash held in historical dollars did not change, comparative balance sheets would show $\$ 6,010$ less in 1974.54

${ }^{50}$ FASB EXPosure Draft, supra note 2, 9 37(c). Preferred stock that is not carried at such amount is restated each year, but only until it reaches its "fixed liquidation price." Id. I 45 .

51 The distribution of the equity in general purchasing power units is constantly shifting because the preferred equity is a fixed number. This redistribution is made directly into common stockholders' equity and is not included in the restated income statement figure for gains and losses from the holding of monetary assets. The redistribution is reflected in computations of restated net income per common share. Id. $1 / \pi$ $49,54(f)$ n.8.

52 Id. 146.

53 Id. 153.

${ }^{54}$ See id. The figure of $\$ 56,010$ is derived from the computation at text following note 49 supra. 
Past dividends are also rolled forward. In this way, a shareholder who has received the same nominal amount in dividends in two successive years is informed that dividends have declined in terms of their general purchasing power. ${ }^{55}$

\section{The Standards of Disclosure}

Should the FASB adopt its price-level proposal, the restated financial statements would appear in the basic disclosure documents of every corporation. The issue, then, is whether the additional statements would aid disclosure or, rather, would prove so confusing to the average investor as to be deemed misleading under rule $10 \mathrm{~b}-5$ standards.

Technical competence in meeting the standards of a profession does not necessarily fulfill the requirements of disclosure. ${ }^{56}$ An attorney who renders an accurate opinion on a contract's legal form, when he knows the economic reality it purports to represent does not exist, may be liable under rule $10 \mathrm{~b}-5{ }^{57}$ Similarly, an accountant who in fulfilling his responsibilities under generally accepted accounting principles knows that economic reality is not being portrayed, may also violate the rule. ${ }^{58}$ The analysis, therefore, must center not on professional standards, but on investor needs. As Judge MacMahon of the Southern District of New York said, "Our inquiry is properly focused not on whether [the accountants'] report satisfies esoteric accounting norms, comprehensible only to the initiate, but whether the report fairly presents the true financial position of [the company] ... to the untutored eye of an ordinary investor." ${ }^{59} \mathrm{He}$ added, "This duty cannot be fulfilled merely by following generally accepted accounting principles." ${ }^{60}$

As early as 1942, the SEC advanced the position that reliance upon generally accepted accounting principles (GAAP) is not a complete defense to charges of inadequate disclosure. ${ }^{61}$

\footnotetext{
${ }^{55}$ No provision is made for presentation of market price of shares adjusted for general purchasing power changes.

${ }^{56}$ See ASR No. 150, supra note 32.

${ }^{57}$ SEC v. National Student Marketing Corp., [Current] CCH FEd. SEC. L. ReP. ff 95,331 (D.D.C. Oct. 21, 1975) (denial of motions for summary judgment).

${ }^{58}$ United States v. Simon, 425 F.2d 796 (2d Cir. 1969), cert. denied, 397 U.S. 1006 (1970).

${ }^{59}$ Herzfeld v. Laventhol, Krekstein, Horwath \& Horwath, 378 F. Supp. 112, 121

(S.D.N.Y. 1974).

${ }^{60}$ Id. at 122. See also 43 CoLo. L. REv. 51 (1971).

${ }^{61}$ Associated Gas \& Elec. Co., 11 S.E.C. 975, 1058-59 (1942).
} 
The unexplained application of GAAP may induce the average investor to draw unwarranted inferences about company performance. Knowledge of technical accounting rules may be necessary to understand why such inferences should not be drawn. For example, in Kaiser-Frazer Corp. v. Otis \& Co. ${ }^{62}$ a Securities Act case, the use of GAAP created a serious misunderstanding.

Kaiser-Frazer's prospectus included a summary of earnings:

Period Net Profit or Loss

Two months ended

November 30,1947 $9,406,478$

Quarter ended

December 31, 1947 (4) ........................ 13,415,861 ${ }^{63}$

Footnote (4) stated that the information "reflects various substantial year end adjustments including provision for certain reserves and a material increase in inventories to conform to the results of the complete physical inventory taken by the Corporation as of December 31, 1947."64 Although no separate December profit figure was stated, subtraction of the two-month figure from the quarter figure indicated a December profit of about $\$ 4$ million. In fact, about $\$ 3.1$ million of "December profit" resulted from inventory adjustments not allocable to December. The court concluded:

The district court found that the "summary of consolidated sales and earnings for the final quarter of the year 1947 . . was computed in accordance with accepted accounting procedures," and that it was not misleading. With this conclusion we cannot agree. For, regardless of whether its accounting system was a sound one, Kaiser-Frazer stated its earnings in such a way as to represent that it had made a profit of about $\$ 4,000,000$ in December 1947. . . . The footnote that appeared in the prospectus ... was entirely insufficient [to disclose the source of the putative profit]. No one reading it would have been put on notice that the actual profit for

${ }^{62} 195$ F.2d 838 (2d Cir.), cert. denied, 344 U.S. 856 (1952).

${ }^{63} \mathrm{Id}$. at 841 (footnote omitted).

${ }^{64} \mathrm{Id}$. at 842. 
December was less than a fourth of what was indicated by the table. ${ }^{65}$

In this case, the court suggested, additional footnotes beyond the call of generally accepted accounting principles would have resolved the antifraud problem. ${ }^{66}$

Neither the courts nor the SEC, however, has generally been willing to accept as full disclosure information intelligible only to sophisticated investors and professionals. ${ }^{67}$ The issuer is free to go beyond the minimum standards of full disclosure and to reveal information that requires professional analysis to be of aid to the investor. ${ }^{68}$ But such additional disclosure must be so structured as not to confuse the average investor. ${ }^{69}$

An issuer's departure from a relatively acceptable mode of disclosure, historical cost, may also shift the frontier of required disclosure. Rule 10b-5 requires disclosure of "a material fact

${ }^{65}$ Id. at 843 (footnote omitted).

66 "The source of the profit as stated in the prospectus for December could have been readily disclosed by a footnote to the earnings table." $I d$.

${ }^{67}$ See, e.g., Feit v. Leasco Data Processing Equip. Corp., 332 F. Supp. 544 (E.D.N.Y. 1971); F. Wheat, Disclosure to Investors 77-78 (1969); $c f$. Schneider, Nits, Grits, and Soft Information in SEC Filings, 121 U. PA. L. REv. 254 (1972).

${ }^{68}$ The proper resolution of the various interests lies in the inclusion of a clearly written narrative statement outlining the major aspects of the offering and particularly speculative elements, as well as detailed financial information which will have meaning only to the expert.

Feit v. Leasco Data Processing Equip. Corp., 332 F. Supp. 544, 566 (E.D.N.Y. 1971). Professional "middlemen" and their sifting and analysis of data have been assigned a necessary role in the securities markets. See Cohen, Truth in Securities Revisited, 79 Harv. L. Rev. 1340, 1353, 1377-78 (1966); Sowards, The Wheat Report and Reform of Federal Securities Regulation, 23 VAND. L. Rev. 495, $498-502$ (1970). But the role has been promoted by unnecessary curtailment of the disclosure by the issuer of soft information, analyses, projections, and plans. See Schneider, supra note 67.

${ }^{69}$ See Sunray DX Oil Co. v. Helmerich \& Payne, Inc., 398 F.2d 447 (10th Cir. 1968) (proxy statement). In that case the oil company failed to reveal information concerning the potential of an offshore drilling tract. The court quoted with approval the SEC amicus curiae brief:

[I]t is altogether probable that investors unfamiliar with the technical aspects of the oil and gas business-and these would likely include most shareholders of major oil companies such as here involved-would ignore or misconstrue the technical but extremely significant difference between "proved" and "probable" oil reserves. Investors might well regard the two as interchangeable, which they definitely are not, and would attribute to any numerical estimates of probable reserves a degree of certainty which is not warranted."

Id. at $45 \mathrm{I}$.

Although the SEC suggested the information was conceivably allowable, the court said inclusion of the information could have been a violation of disclosure standards. Both court and SEC said non-disclosure was permissible. 
necessary in order to make the statements made, in light of the circumstances under which they were made, not misleading "70 Disclosure beyond the minimum may require other disclosure; ${ }^{71}$ hinting at facts may make those facts, not theretofore deemed material, material.

In testing the FASB draft the crucial question is whether the proposal would give the average investor comprehensible information that is relevant, complete, and not so confusing as to mislead.

\section{Disclosure and the FASB Proposal}

If the FASB draft is adopted, the limited explanations in the form of captions and footnotes anticipated by the Board may prove not to be sufficient or appropriate disclosure. The proposal may fail in two respects. First, assuming arguendo a legitimate use for price-level statements, explanations of the differences between price-level and current value or replacement cost accounting may fail unless they describe the exact quantitative differences. Second, actual appreciated values are material information not currently disclosed solely because of accounting convention. Once the well-known historical cost convention is breached, that material information itself, not merely a loose approximation such as price-level adjustments, must be disclosed.

\section{A. Failure to Explain}

Once the restated figures are set out, the average investor probably will draw unwarranted inferences as to current asset values. The FASB draft recognizes this problem. As a solution, the draft calls for a footnote disclaiming any similarity to replacement cost, liquidation value, or any other current value method of accounting. ${ }^{72}$ Yet with that disclaimer the investor is left at large. The suggested footnote says:

Amounts shown in this summary of financial information stated in units of general purchasing power are the corresponding dollar amounts restated as if the transactions underlying the financial statements had taken place in dollars whose general purchasing power was

${ }^{70} 17$ C.F.R. $\$ 240.10$ b-5(b) (1975).

${ }^{71} \mathrm{Cf}$. Mitchell v. Texas Gulf Sulphur Co., 446 F.2d 90 (10th Cir.), cert. denied, 404 U.S. 1004 (1971).

72 FASB Exposure Draft, supra note 2, at 68. 
equivalent to the general purchasing power of the dollar [in current dollars]. ${ }^{73}$

With such verbiage the average investor could, if he reads the note at all, ${ }^{74}$ easily assume that if the company had to use today's dollars today, it would have to spend the restated amount to replace a given asset. That is exactly the wrong inference. Only by coincidence will changes in general price levels accurately reflect the changes in actual value of specific assets. ${ }^{75}$ The supply and demand factors that produce a particular price for a particular good do not vary over time in a set relationship to the general economy, which is measured by the GNP Implicit Price Deflator. ${ }^{76}$ The price of a good may fluctuate at a rate or even in a direction different from that of the deflator.

For example, the GNP Implicit Price Deflator rose $10.2 \%$ in 1974 over 1973. For the same period indexes of specific commodity prices often reflected greater gains: ${ }^{77}$

Wholesale Prices

$19.0 \%$

Industrial Commodities

(wholesale excluding foodstuffs)

$22.0 \%$

Farm Products, Processed

Foods and feeds (wholesale)

$11.5 \%$

Energy (gasoline, oil, fuel, ice, electricity, gas)

$30.4 \%$

Consumer Price Index

Further generalized descriptions probably would not clarify the statements. ${ }^{78}$ Perhaps detailed footnotes explaining specific

${ }^{73}$ Id .

${ }^{74}$ See notes $118-20$ infra \& accompanying text.

${ }^{75}$ Id. If 8.

${ }^{76} \mathrm{Cf}$. ARS No. 6, supra note 4, at 6-8.

77 U.S. DeP't of Commerce, 55 Survey of CuRrent Business, Jan. 1975, at 8 (preliminary figures differing slightly from the revised indexes). Separating actual value from price-level effects would be much simpler if some historic purchasing power unit, say the 1929 dollar, were selected. Using the word dollar itself may be unwise, if the goals of price level accounting have been accurately portrayed. See FASB Exposure DRAFT, supra note 2, ITा 65-69. trend:

${ }^{78}$ Such generalized statements would probably contribute to a much lamented

In at least some instances, what has developed in lieu of the open disclosure envisioned by the Congress is a literary art form calculated to communicate as little of the essential information as possible while exuding an air of total candor. Masters of this medium utilize turgid prose to enshroud the occasional 
disparities between current sale price or replacement value and price-level value would be helpful. ${ }^{79}$ But the question arises how refined the footnotes must be. These disclosing footnotes eventually could become a third set of figures based on replacement or sale value. Even if all the current values need not be disclosed, someone must be paid to appraise and certify that the general price-level information does not distort current values. Nor is asset valuation the sole area of distortion that would require additional disclosure. Serious problems emerge with accounting for income ${ }^{80}$ and for shareholder equity. ${ }^{81}$ And at this high cost, probably higher than that required under the SEC's own proposal, ${ }^{82}$ the benefit of price-level accounting is relatively insubstantial.

Price-level adjusted data have rarely been deemed relevant by those who have had the opportunity to use such information. A 1972 study by the Canadian Institute of Chartered Accountants concluded:

In Canada, both accountants and users display little interest in price-level restated reports. The latter remark is not based on an extensive empirical investigation, but rather is the view expressed to the author by many people interviewed-including officials of two companies which incurred the cost of introducing price-level re-

critical revelation in a morass of dull, and-to all but the sophisticates-useless financial and historical data.

Feit v. Leasco Data Processing Equip. Corp., 332 F. Supp. 544, 565 (E.D.N.Y. 1971).

79 The need for such explanations is generated in part by a seemingly off-handed choice of the exposure draft. The unit of measurement chosen is the general purchasing power of the dollar at the most recent balance sheet date. FASB ExPOSURE DRAFT, supra note 2, I 36. But using current dollars is not necessary to the purported goals of the proposal. See id. II 7, 9. Why not call the unit a "GPPU"or a "shrdlu" to dispell confusion? "[I]t would be desirable to abandon the word . . .-since that word misleadingly connotes some moderately rational judgment-and to substitute some neutral term, devoid of misleading associations, such as "aluation," or, perhaps better still, 'woosh-woosh.' " Old Colony Bondholders v. New York, N.H. \& H.R.R., 161 F.2d 413, 450 (2d Cir.) (Frank, J., dissenting in part), cert. denied, 331 U.S. 858 (1947). But such options would not mesh with the tax reform goals that remain implicit in the proposal. See notes 155-63 infra \& accompanying text.

${ }^{80}$ See notes 121-28 infra \& accompanying text.

${ }^{81}$ See notes 129-54 infra \& accompanying text.

${ }^{82}$ The SEC has specifically solicited comment on two possible cost saving devices. First, the Commission has asked about labeling the replacement costs "unaudited," in order to reduce the costs of using independent public accountants. Second, the SEC has asked about limiting the requirement of disclosure to larger companies. SEC Securities Act Release No. 5608, supra note 20, at 85,578. 
stated reports, but would not incur the small cost of maintaining the system for a second year. ${ }^{83}$

Apparently American management feels similarly. The FASB draft states that few businesses in the United States have used price-level reporting despite extensive literature calling attention to it. ${ }^{84}$

Whether it be the SEC or the accounting profession, guardians of the public interest are wont to give more information than investors wish to have. No more than a waste of paper would be involved were it not for the overall confusion generated by such surplusage.

B. Current Value or Replacement Cost as

Material Information Disclosure of Which is Necessary to Avoid Misleading Investors

\section{Assets}

The difficulties with the FASB proposal's approach to asset valuation also illustrate a legitimate need of investors: the ability to determine current values of assets held and used by a corporation. If investors need balance sheets reflecting market values, but rules of accounting assure that such values are not reflected, an inevitable clash arises between accounting principles and the full disclosure provisions of the federal securities laws. ${ }^{85}$ Indeed, several cases, although generally read more narrowly, indicate that in inflationary times disclosure of current value or replacement cost may be almost a necessity. ${ }^{\mathbf{8 6}}$

Several major cases have dealt with the question of the disclosure required by federal securities law when a corporation holds substantially appreciated assets. Unfortunately these cases have had atypical fact patterns. Because of the peculiar positions of the companies, realization of the appreciation was possible only through sales outside the normal course of business. From these cases the notion has emerged that only imminent liquida-

${ }^{83}$ L. Rosen, Current Value Accounting and Price-Level Restatements 50 (1972).

${ }^{84}$ FASB EXPosure Drarr, supra note 2, 158.

${ }^{85}$ See Manne, Accounting and Administrative Law Aspects of Gerstle v. Gamble-Skogmo, Inc., 15 N.Y.L.F. 304, 318-19 (1969). See also M. Backer, CuRrent Value Accounting 79-105 (1973).

${ }^{86}$ See notes 87-120 infra \& accompanying text. 
tion or a similar situation makes current asset values material to investors. This reading, however, is too narrow. A more appropriate reading is that disclosure of appreciated values is required when it is likely that such values will be realized, but only if the values may be ascertained with reasonable certainty. This broader reading recognizes the need to account for inflation, but casts doubt upon the propriety of techniques suggested by the FASB.

Speed v. Transamerica Corp..$^{87}$ focused on the non-disclosure of the market value of the Axton-Fisher Tobacco Corporation's inventories, which had dramatically appreciated in value. Transamerica purchased shares of Axton-Fisher in a general tender offer without disclosing the appreciation. The court found a violation of rule $10 \mathrm{~b}-5$ because at the time Transamerica made the offer to purchase, it intended to use the controlling interest it would obtain to realize the appreciation by liquidating AxtonFisher.

The non-disclosure of the inventory profit according to historical and orthodox practices may have had little significance-considered abstractly. The reason could be urged that while such fact might not be known to each individual shareholder, it would, however, be known in tobacco and financial circles. This knowledge would, of necessity, be reflected or discounted in the price at which the stocks sold on the public exchanges. In fact, plaintiffs and the SEC both reluctantly admitted the asset or real value would not be a significant factor in the absence of a plan to liquidate, etc. . . Had there been no plan to liquidate, etc., Transamerica could have given information on both the vastly improved earnings of Axton-Fisher and the vastly increased value of the tobacco leaf industry $[s i c]$ and still secure the stock at about the stated [tender-offer] prices, which were substantially above the market value. ${ }^{88}$

Under normal conditions this abstraction is, of course, nonsense. If the tobacco had increased greatly in value, its future sale in the ordinary course of business at higher prices would create increased profits. Such anticipated increase in future earnings would have driven up the price of Axton-Fisher stock.

8799 F. Supp. 808 (D. Del. 1951), modified and aff d, 235 F.2d 369 (3d Cir. 1956).

${ }^{88} I d$. at 825-26 (footnote omitted). 
But Axton-Fisher was not operating under normal conditions. It was subject to a ninety percent excess profits tax, so that the increase in value could not be realized in the ordinary course of business. ${ }^{89}$ Transamerica was advised that through liquidation of a controlled corporation whose stock had been purchased, the tobacco could be distributed in kind to shareholders (primarily Transamerica) at capital gains rates. ${ }^{90}$ Resale of the tobacco would not produce excess profits, presumably, because its basis would be the fair market value at the date of distribution by Axton-Fisher to Transamerica. ${ }^{91}$ In this situation the court was correct in stating that the inventory appreciation would have little significance absent the possibility of liquidation. In this case, failure to disclose appreciation materially misled investors as to potential future profits. Absent the excess profits tax, failure to disclose appreciation also would have misled investors about potential future profits, regardless of liquidation plans.

Speed also implies that following FIFO accounting-an analogue to historical cost-in severely inflationary times may be misleading in that it conceals the impossibility of sustaining the inflated profit levels. A company with appreciated FIFO inventory can, by raising prices, report a large profit in the year in which the sale of such inventory takes place. If similar appreciation does not continue, the company has earned a one-time profit that should not be taken as an indication of future profits. Perhaps only disclosure of actual changes in value would make clear the nature of the reported profits. ${ }^{92}$

Appreciated capital assets were central to the decision in Gerstle v. Gamble-Skogmo, Inc. ${ }^{93}$ Gamble-Skogmo acquired General Outdoor Advertising Co. by merger in 1963. From 1961 to 1963, General was the largest company in the outdoor advertising business in the United States. It operated thirty-six branches and owned about 600 parcels of real estate on which its facilities and offices were located. ${ }^{94}$ In 1961, General's business declined, and in 1962 General began to sell its plants. It was able to realize

${ }^{89}$ Id. at $823,837-38$; see Revenue Act of 1942 , ch. $619, \S 202,56$ Stat. 899 (repealed 1945).

90 99 F. Supp. at 823.

${ }^{91}$ At least the district court so assumed. Id. at 838.

${ }^{92} \mathrm{Cf}$. Bowman \& Bourdon, Inc. v. Rohr, 296 F. Supp. 847 (D. Mass. 1969), aff'd per curiam, 417 F.2d 780 (1st Cir. 1969).

${ }^{93} 298$ F. Supp. 66 (E.D.N.Y. 1969), modified and aff'd, 478 F.2d 1281 (2d Cir. 1973)

${ }^{94} I d$. at 74 . 
amounts well in excess of book values of the properties. ${ }^{95}$ This appreciation was apparently due to the purchasers' ability to operate the plants more efficiently, to realize a larger cash flow from the properties, and to take greater tax deductions than could General. The properties had been almost fully depreciated for tax purposes by General. ${ }^{96}$ The purchasers obtained a new tax basis upon purchase and could take larger depreciation deductions.

Rule $14 a-9^{97}$ under section 14 of the Securities Exchange Act of $1934^{98}$ prescribes full disclosure standards for proxy solicitations analoguous to those of rule 10b-5. At issue in Gerstle was whether the merger proxy statement sent to General shareholders was misleading in failing to disclose sufficiently the appreciated values of General's properties, in failing to disclose sufficiently its plans to continue to sell these properties, or both.

The SEC, relying on its brief in Speed, ${ }^{99}$ took the position that asset appreciation must be disclosed if "liquidation of those assets is intended or can reasonably be anticipated."100 The court, on the other hand, read Speed more narrowly. Current value could be disclosed only because the tobacco "was actively traded and ... market value could be ascertained with reasonable certainty on the basis of actual sales. No 'appraisal' of market value was required, and the dangers that the SEC has perceived in the disclosure of appraised values were not present."101

Somewhat inconsistently, the court nevertheless found that General's proxy statement was materially misleading.

We rest our decision on the point that ... the Proxy Statement must be faulted, on traditional grounds going back to the Speed case . . . as failing adequately to disclose that, upon completion of the merger, Skogmo intended to pursue aggressively the policy of selling [General's] plants, which had already yielded such a substantial excess of receipts over book value. ${ }^{102}$

Of course the information relating to intent to sell would be

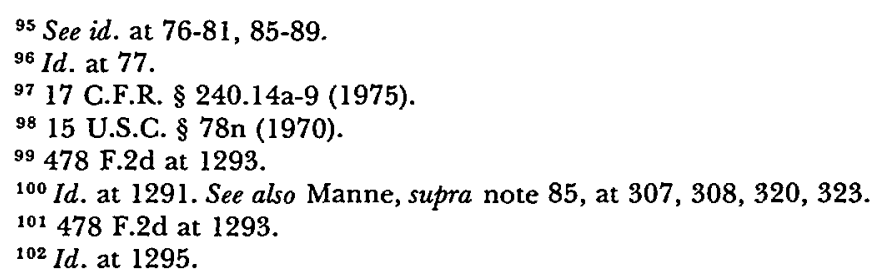


meaningful to investors only if they realized that plant selling prices exceeded book value. To avoid misleading omissions, full disclosure would also reveal the price, exactly what the court indicated was not required to be set out. ${ }^{103}$

As in Speed, the situation in Gerstle was one in which the corporation could realize the increased asset values only by sale other than in the ordinary course of business. General could not duplicate the economies available to potential purchasers; it could not obtain the depreciation write-offs open to purchasers.

More typically, appreciation of capital assets can be realized by means other than liquidation. Competitors who have been required to assemble capital assets at higher prices will be unable to compete effectively so either sales may rise or prices may be increased to reflect more closely those of competitors who entered the industry when acquisition costs were higher. Thus, to the investor appraising future earnings, appreciation is an important factor. The high profit figures are misleading, though, as predictors for the long run. Replacement of capital assets at higher costs soon ends the advantage to a going concern of asset appreciation. The depreciation charges based on lower historical costs result in higher profits than can be expected in later periods when depreciation is based on the cost of replacement assets.

Speed and Gerstle, then, may represent the application to atypical situations of a rule that merits broader application: Where appreciation of asset value is likely to be realized, it is misleading under the standards prescribed by rule $10 \mathrm{~b}-5$ and comparable provisions not to disclose current values of assets. Liquidation was critical to Speed and Gerstle only because it was the sole method of realization. But with a rule stated this broadly, the well-accepted use of historical cost is improper.

Although the argument against historical cost itself may be strong, the thesis here is narrower. Historical cost may be defended as having its distortions justified in most cases by a long history of custom and convention. We may assume that the average investor is aware of this system of accounting. He may not understand why it is used nor think much of its utility, but he knows that it creates distortions and that he should place little reliance on the balance sheet it produces. No other method, price-level accounting in particular, has such a long history. A

${ }^{103} I d$. at 1302. 
system proposing to depart from tradition must put forward justifications more convincing than those offered by the established historical cost approach. ${ }^{104}$ The new system has not made an implicit full disclosure through custom and convention.

John C. Burton, the SEC's Chief Accountant, has made a similar analysis:

Not only will PuPU accounting [an acronym for accounting in "purchasing power units"] suffer all the disabilities of any historical cost system, but it will have an additional significant potential for misleading investors arising out of the fact that it will appear to be an improvement when it is in fact not. This danger is particularly acute if the PuPU system is annointed [sic] by the Financial Accounting Standards Board as constituting significant and valuable new information. ${ }^{105}$

The acuteness of the danger is emphasized by the limited theoretical usefulness to investors of a price-level system. A report of the Canadian Institute of Chartered Accountants concluded: "Probably the only situation where price-level restatements would be a sensible choice would be when inflation was so rapid that a strong statistical relationship developed between restated costs and such needed sums as replacement cost or resale prices."106

Thus a departure from historical cost mandates a disclosure that provides significant material information to the investor. Price-level accounting does not suffice. It only mutates the distortions of historical cost; it does not transcend them. The reform cannot go only halfway. ${ }^{107}$

The opinion of the district court in SEC v. Bangor Punta Corp. ${ }^{108}$ supports this conclusion. In a 1964 merger, Bangor

${ }^{104}$ An appropriate analogy is the "good samaritan rule" of tort law. Though one has no duty to assist an injured or endangered person, once one undertakes to do so he must act with reasonable care. Restatement (SECond) of ToRTs $\$ \$ 314,323$ (1965). Such assistance may cause other potential rescuers to refrain from acting, in reliance upon the aid apparently being rendered. Once the investor is told he is being saved from the traps of historical cost, there appears a duty to provide a reasonable rescue, not one replete with new, undisclosed traps. See Shapiro v. Merrill Lynch, Pierce, Fenner \& Smith, Inc., 353 F. Supp. 264, 278 (S.D.N.Y. 1972), aff'd, 495 F.2d 228 (2d Cir. 1974).

${ }^{105}$ Burton, Financial Reporting in an Age of Inflation, $139 \mathrm{~J}$. Accountancy, Feb. 1975, at 68, 70; see Burton, Accounting that Allows for Inflation, Bus. WEEK, Nov. 30, 1974 , at 12,14 .

${ }^{106}$ L. Rosen, supra note 83 , at 8 .

${ }^{107}$ See notes 78-82 supra \& accompanying text.

${ }^{108} 331$ F. Supp. 1154 (S.D.N.Y. 1971), aff'd in part, rev'd in part sub nom. Chris-Craft 
Punta had acquired ninety-eight percent of the stock of Bangor and Aroostock Railroad, which had been among the assets of the company acquired by Bangor Punta. Generally accepted accounting principles would have permitted Bangor Punta to place the railroad stock on its balance sheet at the amount given for it in the merger- $\$ 29.8$ million. ${ }^{109}$ Instead, Bangor Punta chose to carry forward the book value of the railroad stock as it appeared on the books of the acquired company- $\$ 8.1$ million-because of a strong possibility that the railroad stock would be sold immediately. The sale would have produced a large loss if the cost of the stock were recorded at $\$ 29.8$ million. When the sale did not take place, Bangor Punta in 1965 obtained an appraisal of the railroad and, consistent with that appraisal, carried its investment in the railroad at $\$ 18.4$ million.

Several years later, while Bangor Punta was negotiating to sell its railroad stock for $\$ 5$ million, it filed with the SEC a registration statement that continued to carry the Railroad stock at $\$ 18.4$ million. At the time of the filing, the court found, a sale at the $\$ 5$ million offered was not yet a reasonable probability. Nevertheless, the court found that Bangor Punta had violated rule $10 \mathrm{~b}-5$.

The Court is aware of no principle of accounting or of fair disclosure which would justify a failure to update a constructed carrying figure which may have reflected approximate fair value in 1965 but which was almost four times the offer of a willing buyer (and the only willing buyer) in $1969 \ldots$. . Consistency of fair disclosure required exposure of circumstances which so clearly rendered obsolete an appraisal made four years earlier.

The Court concludes that the registration statement ... was misleading in its failure to disclose the circumstances surrounding the negotiations for sale of the [railroad] interest. In so holding especial note is taken of the unique "valuation" nature of the $\$ 18.4$ million figure .... The present conclusion is not necessarily to be taken as applicable in cases where book carrying fig-

Indus., Inc. v. Piper Aircraft Corp., 480 F.2d 341, 383 (2d Cir.), cert. denied, 414 U.S. 910, 924 (1973).

${ }^{109} 331$ F. Supp. at 1156. 
ures are in accordance with principles of conventional transactional accounting . ... ${ }^{110}$

The court appears to be saying that carrying the stock at the even more inflated figure of $\$ 29.8$ million, in accordance with historical costs, may not have been misleading. But once departures from historical cost are made, it appears that a partial adjustment that does not reflect true current value is insufficient disclosure. ${ }^{111}$

The Second Circuit, considering the case on appeal, accepted the conclusion below that the $\$ 18.4$ million figure was materially misleading. A majority nevertheless affirmed the lower court's refusal to grant an injunction. ${ }^{112}$ Dissenting on that issue, Judge Timbers described the balance sheet figure as "unrealistic." 113 Implicit in that description seems to be the notion that book value should reflect current market value-a proposition contrary to presently accepted accounting principles. Judge Mansfield, one of the majority on this issue, accepted the appraised figure as "misleading," but found Bangor Punta's failure to round out the picture insufficiently flagrant. "A person able to read a balance sheet would probably have recognized that such 'historical' cost did not necessarily represent current liquidating value."114 But the figure at issue was not historical cost, and that fact undercuts the judge's assumption of financial literacy.

Literature aimed solely at professional accountants provides strong evidence that confusion will be widespread among average investors. Caveats to avoid confusing general price level changes with current market values are repeatedly included. The FASB draft itself indicates that "hundreds of articles and a number of books and research studies have been written on the subject [of price-level accounting]."115 Despite this, the third paragraph of the preface cautions its professional readers: "Expressing financial information in units of general purchasing power should not be confused with the proposal that financial

${ }^{110} I d$. at 1161-62.

${ }^{111} C f$. M. BACKER, supra note 85, at 105.

${ }^{112} \mathrm{Judge}$ Timbers wrote the opinion for the court, but dissented on the issue of refusal to grant an injunction. Judge Gurfein and Judge Mansfield formed the majority on that issue. 480 F.2d at 384-90 \& n.38, 393-95, 403-07.

${ }^{113} \mathrm{Id}$. at 388 ; see id. at $366-69$.

$114 \mathrm{Id}$. at 406 ; see id. at 404.

115 FASB EXPosure Draft, supra note 2, I 58. 
statements reflect changes in the specific prices ('current values') of goods held or obligations owed by an enterprise while they are held or owed."116

The FASB's answer to this confusion is to add in footnote form an explanation of price-level procedures, including a statement to the effect that the figures "do not purport to represent selling price, replacement cost, or any other measure of the current value of the assets or the prices at which transactions would take place currently."117

One survey concluded that the average small shareholder spends just under fifteen minutes on the entire annual report of a corporation in which he has invested. ${ }^{118}$ Another survey of investors with at least one round-lot investment in a listed company indicated that only 34.9 percent of the respondents read somewhat thoroughly the footnotes to the financial statements in annual reports that they receive. ${ }^{119}$ In light of these findings it is unrealistic to assume that the proposed footnote reference will change investor impressions of balance sheet figures. As one analyst said of typical investors, "They barely if at all understand current financial statements, and to give them another set would thoroughly confuse and often mislead them."120

\section{Income and Management Performance}

The use of price-level adjustments in the income statement is an attempt to factor out increases in income caused only by inflation, by, for example, adjusting depreciation charges and inventory costs. It is also an attempt to reflect real changes in general purchasing power of the company that arise from holding monetary items. As with the balance sheet, the restated income statement may mislead investors more than if no adjustments were made.

The first source of possible confusion in the use of such adjusted income statements is the tenacity with which investors hold to traditional measures of financial performance. The average investor is accustomed to profits being measured in dollars

${ }^{116} I d$. iii.

117 Id. 68.

118 Georgeson \& Co., supra note 27, at 4.

119 M. Epstein, The Usefulness of Annual Reports to Corporate ShareHOLDERS 39 (1975).

120 Gerald I. White, financial analyst at Sterling, Grace \& Co., New York, quoted in Wall St. J., Nov. 12, 1975, at 42, col. 2. 
of different and indeterminable purchasing power. He has internalized the notion that profit figures must be viewed in light of changed purchasing power. A subjective adjustment is no doubt made. But formalizing this adjustment may cause more confusion than do the present reporting practices.

More specific and technical objections attack the underlying assumptions of price-level income measurement. William Bradford has pointed out, for instance, that an assumption of the FASB proposal-that inflation is unanticipated-will lead to inaccurate evaluations of management performance. ${ }^{121}$

Under the FASB proposal, any company in a net monetary asset position realizes general purchasing power losses. ${ }^{122}$ But the holding of net monetary assets may not result in real economic loss if management performs well. "If the interest rate on monetary items has been adjusted to compensate exactly for an inflation, then the firm will not lose or gain from holding monetary items." ${ }^{23}$ The FASB proposal provides information insufficient to determine whether management has done a good job or a poor one in anticipating inflation and dealing with it. The proposed method of reporting could grossly mislead investors concerned with separating management's operational performance from its financial performance in dealing with rising price levels. Two examples illustrate the point.

Suppose that in a year in which general price levels rise by ten percent, Company $X$ holds net monetary liabilities of $\$ 500,000$. A general price level gain of $\$ 50,000$ would be recorded on the income statement. Assume, however, that $X$ 's creditors, anticipating inflation, raised interest charges on $X$ 's obligations by $\$ 60,000$. Management, by borrowing at these increased rates, has caused the corporation to suffer an economic loss. The additional $\$ 60,000$ interest expense would, of course, show up in the income statement, but it would be attributable to operational costs, not to inflation. Even though the bottom line income statement figure will remain the same whether or not gains and losses on monetary items are shown separately from operating gains and losses, the separate income statement classification of these items would create the appearance that management has dealt skillfully with inflation. In fact, it has managed its affairs in

121 Bradford, Price-Level Restated Accounting and the Measurement of Inflation Gains and Losses, 49 Accounting Rev. 296 (1974).

${ }^{122}$ See FASB Exposure Draft, supra note 2, 976.

123 Bradford, supra note 121 , at 298. 
the face of anticipated inflation rather poorly by failing to predict more accurately that creditors had overestimated future general price-level increases. ${ }^{124}$

Suppose management of Company $Y$, finding itself in the position of a net creditor, raises its interests charges to borrowers (or reduces the time in which customers can pay without penalty charges). Company $Y$ 's price-level income statement would show a general purchasing power loss because the company holds net monetary assets. The offsetting gains from increasing interest in anticipation of inflation would appear at best in other income items. Some adjustments might not appear at all. If, for instance, management forces credit customers to pay more promptly, no increase in income would appear because the opportunity cost of extending credit for longer periods is not stated explicitly under normal accounting practice. ${ }^{125}$ Again management's skill, or lack thereof, in dealing with inflation would be submerged in figures other than general purchasing power gains and losses. This may be no worse theoretically than the present state of affairs. The investor, however, would be presented once again, without adequate justification, a set of figures containing misleading implications.

An additional objection to the FASB proposal focuses upon assumptions concerning the particular company's investment or reinvestment policies. As we have already observed, ${ }^{126}$ adjustment of depreciation charges on a basis other than replacement cost of assets creates an inaccurate starting point for predicting future income. ${ }^{127} \mathrm{~A}$ similar problem exists with reporting pricelevel gains and losses from holding monetary items. Such gain or loss is in effect the difference between the current claim in dollars of such items and the claim the corporation would have in dollars had it held nonmonetary assets instead. Thus a company that suffers a purchasing power loss by holding cash could avoid that loss by investing in inventory or capital assets. Attributing purchasing power gains or losses to companies in this manner assumes that they had opportunities to invest in assets that

124 Bradford considers in detail mathematical representations of price-level gains and losses in the context of anticipated inflation. Id.

${ }^{125} \mathrm{Cf}$. id. 300.

126 Text following note 103 supra. But of. Comment, Depreciation in the Courts, 9 LAND \& WATER L. REv. 633, 640-44 (1974).

${ }^{127}$ See Revsine \& Weygandt, Accounting for Inflation: The Controversy, $138 \mathrm{~J}$. Accountancy, Oct. 1974, at 72, 76. 
change in exact accordance with the GNP Implicit Price Deflator. In fact, few companies, other than perhaps the largest conglomerates, have the option of investing in such diverse areas of the economy as would be required to match overall GNP changes. ${ }^{128}$

If a company is in the business of selling electrical appliances at retail, it may alter its position in monetary items primarily by changing inventory levels. It may purchase more inventory to lessen monetary assets or purchase less inventory to reduce monetary liabilities. If it anticipates that the price level in historical dollars of electrical appliances will drop by one percent in the next year, even though general prices levels will rise by ten percent, assuming no alternative investments, management ought to hold cash rather than purchase extra inventories. Such proper economic conduct, though, would generate purchasing power losses for the year in price-level financial statements. Investment in an asset whose historical-dollar price is increasing at six percent a year would be better economically than retention of monetary assets and would also eliminate a "holding loss," although in general purchasing unit terms the investor would still be falling behind inflation. Computing holding gains or losses thus diverts the reader of the financial statement from measuring the true ability of management to cope with inflation.

To the average investor, the FASB's proposal offers a halfway step toward more accurate measurement of management performance. But again, a partial adjustment that induces reliance by investors on its accuracy in terms of real economic and managerial results may be worse than retaining the present figures that at least are understood to be deficient in some respects.

\section{Shareholders' Equity}

The FASB proposal also poses considerable disclosure problems in the reporting of shareholders' equity. The shareholders' equity accounts, in separating retained earnings from capital stock and paid-in surplus, generally isolate funds that may legally be distributed to shareholders as dividends. ${ }^{129}$ Legally the amount available for distribution is the amount defined by the

${ }^{128}$ Id. 76-78.

129 Accounting practice uses legal definitions of par value and stated value to determine entries in capital stock and paid-in surplus accounts. See, e.g., H. SELlin, AtTorney's Handbook of Accounting 4-4 to 4-5 (1971). 
applicable corporation statute as available for dividends. ${ }^{130}$ Economically, the maximum amount that ought to be distributed is that which permits the business to continue operating at its present physical levels, that is, the amount available after meeting expenses and creating a fund for replacement of assets. ${ }^{131}$ The FASB proposal measures neither of these amounts adequately.

Some have suggested that present dividend law should be interpreted to incorporate price-level adjustments. ${ }^{132}$ Their rationale embodies the economist's notion of capital. It suggests that the amount available for dividends should be restricted by the higher depreciation charges (and resulting lower earnings) required by price-level restatements, because the higher charges are necessary to preserve sufficient capital for asset replacement. This concern with business continuation, however, is primarily one of shareholders. It is relevant to dividend regulation only to the extent that state legislatures intend dividend statutes to protect shareholders as well as creditors.

Some commentators have indeed suggested that modern dividend statutes are intended to protect shareholders as well as creditors. ${ }^{133}$ But, at best, shareholder protection is only a subsidiary aspect of dividend control, and to characterize present dividend law as embodying notions of price-level adjustments in order to protect shareholders seems clearly incorrect. ${ }^{134}$ Dividend restrictions are primarily intended to protect creditors. ${ }^{135}$

${ }^{130}$ See, e.g., H. Henn, Handbook of the Law of Corporations $\$ \$ 320-21$ (2d ed. 1970).

131 The point is often made in connection with the question of appropriate depreciation charges. See, e.g., 1 A. Dewing, The Financial. Policy of Corporations 546-51 (5th ed. 1953); Revsine \& Weygandt, supra note 127, at 75.

${ }^{132}$ See Finn, Price-Level Accounting for Corporate Dividends, 12 Santa Clara Law. 59 (1972); Comment, Significance of Appreciation and Changing Price Levels in Corporate Dividend Policies, 35 Mich. L. REv. 286, 287, 289 (1936).

${ }^{133}$ See, e.g., H. Ballantine, Corporations 572 (rev. ed. 1946); Hackney, The Financial Provisions of the Model Business Corporation Act, 70 HARv. L. REv. 1357, 1364-65 (1957). This notion finds support, for example, in statutes requiring shareholder consent to the use of capital surplus as a dividend source. See, e.g., ABA-ALI MODEL Bus. CoRP. ACT § 46(b) (rev. ed. 1969).

${ }^{134}$ See Dean, Provision for Capital Exhaustion Under Changing Price Levels, 65 Harv. L. REv. 1339, 1340-43 (1952).

${ }^{135}$ See, e.g., Wood v. Dummer, 30 F. Cas. 435,436 (No. 17, 944) (C.C.D. Me. 1824). Dividend limitations have been described as attempts to protect the corporation's capital "for the benefit of third parties who deal with it." ABA-ALI Model Bus. Corp. Act ANN. $\$ 45(a)$, I 2, at 890 (2d ed. 1971). Statutes often provide protection for preferred shareholders' liquidation preferences. See, e.g., ABA-ALI Model Bus. CorP. Act $\S 21$ (rev. ed. 1969), which specifies that no portion of the consideration received for no-par 
Dividend statutes assume that creditors rely upon the liquidation potential of the business; the statutes do not direct themselves to creditor concern about continued income. These assumptions may be unrealistic. The state corporation law guarantees only that a fixed-dollar amount, decided upon by the entrepreneurs, will not be distributed to shareholders in the form of dividends. ${ }^{136}$ Dividend statutes are essentially disclosure statues, requiring of incorporators, in the words of Gilbert and Sullivan, only "a public declaration to what extent they mean to pay their debts." 137

Just as the dollar amount owed to creditors does not change as general price levels rise, so the nominal dollar cushion protecting the obligation remains constant. ${ }^{138}$ Thus, to the extent that retained earnings accounts are diminished by price-level adjusted depreciation charges, those accounts cease to approximate the amount legally available for dividends.

Nor do the accounts reflect the reserves necessary for asset replacement. The disparity between specific price-level changes and general price-level changes again prevents any but chance correlation between the decreases in retained earnings and the increases in replacement costs of specific assets. ${ }^{139}$ Accountants have always disclaimed any intent to create a replacement fund in making annual depreciation charges, ${ }^{140}$ and general pricelevel adjustments to historical costs are not put forward as chang-

preferred shall be allocated ta capital surplus until the full amount of the preferred's preference upon involuntary liquidation is placed in stated capital.

${ }^{136}$ See H. Hatrield, Surplus and Dividends 3-5 (1943).

137 The full stanza from Utopia Limited is:

Some seven men form an Association

(If possible, all Peers and Baronets),

They start off with a public declaration

To what extent they mean to pay their debts.

That's called their Capital: if they are wary

They will not quote it at a sum immense.

The figure's immaterial-it may vary

From eighteen million down to eighteen pence.

$I$ should put it rather low;

The good sense of doing so

Will be evident at once to any debtor.

When it's left to you to say

What amount you mean to pay,

Why, the lower you can put it at, the better.

The Plays and Poems of W.S. Gilbert 583, 620 (Random House publ. 1932).

${ }^{138}$ See Dean, supra note 134 , at 1342-43.

${ }^{139}$ See text accompanying notes $75-77$, supra.

${ }^{140}$ See 1 A. Dewing, supra note 131, at 543-45. 
ing this notion. ${ }^{141}$ Rather, the shareholders' equity would become merely a residual figure to be plugged into the balance sheet after the "meaningful" adjustments of other items. Restated balance sheets would not separate retained earnings, capital stock and paid-in surplus accounts. Instead, an aggregate figure for common shareholders' equity would be shown. ${ }^{142}$ The justification offered for this lumping is the impracticability of determining when each item in the shareholders' equity accounts arose. ${ }^{143}$

As previously pointed out, the FASB would treat preferred shares as a monetary item, the holding of which creates purchasing power gains during inflationary periods. These gains are credited to the common shareholders' equity. ${ }^{144}$ The full implications of this treatment of preferred have clearly not been considered.

First, the FASB fails to take account of the innumerable variations of preferred shares that may be issued. ${ }^{145}$ Although preferred shares often have a preference both on dividends and on liquidation, they need not be preferred as to both. ${ }^{146}$ Often, two liquidation preference amounts are specified, one for voluntary and the other for involuntary liquidation. ${ }^{147}$ Cumulative preferred stock generally has a liquidation preference that includes accrued but unpaid dividends. ${ }^{148}$ Preferred may often be redeemable. The redemption price frequently is fixed at a premium above its par or stated value. ${ }^{149}$ Shareholders thus are able to protect their bargained-for dividend rate, making it expensive to eliminate the preferred shares when cheaper funds are available.

The FASB draft states, however, that "[p]referred stock shall not be restated to an amount in excess of its fixed liquidation price," 150 without specifying whether it refers to price on voluntary or involuntary liquidation. It also speaks of "preferred stock that is carried in the balance sheet at an amount equal to its

${ }^{141}$ FASB EXPOSURE Draft, supra note 2, I 26.

${ }^{142}$ Id. \ 46.

${ }^{143} \mathrm{Id}$.

144 Id. I 49.

${ }^{145}$ See Buxbaum, Preferred Stock-Law and Draftsmanship, 42 Calif. L. Rev. 243 (1954).

${ }_{146}$ Cf. ABA-ALI Model Bus. Corp. Act $\$ 15$ (rev. ed. 1969).

${ }^{147}$ See, e.g., V. Brudney \& M. Chirelstein, Corporate Finance 169-70 (1972).

${ }^{148} I d$.

149 See, e.g., E. Donaldson \& J. PFahl, Corporate Finance 140 (3d ed. 1969).

150 FASB Exposure DRAFT, supra note 2, ๆ 45. 
fixed liquidation or redemption price,"151 without realizing that this liquidation price may be different from that payable upon redemption. Moreover, cumulative preferred may not have a "fixed" liquidation price, because unpaid accrued dividends generally change the amount payable on liquidation.

Under state dividend law, the restrictions that limit common dividends also apply to preferred dividends. ${ }^{152}$ Retained earnings, therefore, should in part be a measure of the amount of dividends payable to preferred shareholders. Under the FASB proposal, all earned surplus would become common shareholders' equity, ${ }^{153}$ even though preferred holders in fact have an interest in it in whole or in part. For example, although arrearages may have accrued to increase the "fixed liquidation price" of his shares, the preferred holder will see merely a single figure for preferred stock, which he assumes amounts to the fixed dollar amount of the original preference plus arrearages. To the extent that the FASB intends that the preferred be carried at its liquidation preference without added arrearages, the common shareholders' equity includes those arrearages upon which preferred holders have first claim.

The apparent explanation for these inconsistencies is that the drafters were thinking only of redeemable preferred issued by a corporation as an alternative to debt. ${ }^{154}$ In such case, the crucial carrying figure for balance sheet purposes should be the redemption price at the balance sheet date. It is this figure that, in the going concern, is equivalent to the principal amount of a debt obligation. And it is in terms of the preferred shareholder $q u a$ creditor that the reporting in price-level adjusted statements is directed.

In a sense, then, it is the shareholders' equity portion of the balance sheet that is least informative. Yet disclosure under the securities law generally directs itself to security holders, often shareholders. This divergence indicates the problem. Pricelevel accounting is not concerned primarily with reporting to shareholders.

Our final inquiry, then, is to whom is such reporting directed?

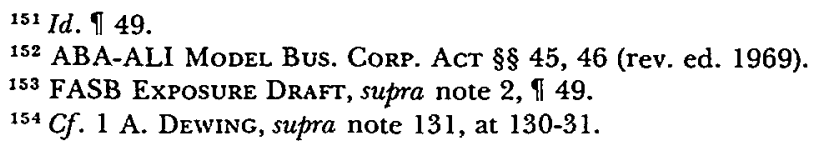




\section{LeVerage For TAX Reform}

As we have observed, management is not eager to have price-level adjusted statements for internal purposes. Investors are likely to be confused by such statements. Why then propose to make such statements mandatory? I would suggest that the answer lies in Accounting Research Study No. 6, which explored at great length the question of reporting effects of price level changes:

Management is understandably reluctant to reduce net income by charges that are not recognized by [sic] tax purposes. But whether an item is, or is not, deductible for tax purposes is determined primarily by political rather than by accounting considerations, and political considerations should not determine accounting practice. Even so, the attitude of management reverses the proper sequence. If the business community wants recognition of price-level changes for tax purposes, it should take the lead by incorporating them in their financial reports. Management and accountants are in a weak position if they seem to favor a procedure for tax purposes which they are unwilling to incorporate into financial statements. ${ }^{155}$

The study then quotes a statement that Treasury Department officials had made it clear that tax changes to recognize the effects of inflation would only follow changes in accounting practice. ${ }^{156}$

SEC Chairman Hills has pointed out that his agency's proposals would be a first step toward "tax reform." The replacement cost footnotes would "better communicate business realities to those who make tax policy and to those responsible for macroeconomic policy."157

Motives are, of course, difficult to decipher; but few other compelling reasons appear to require price-level accounting at this time. ${ }^{158}$ The FASB in its exposure draft states that, "general purchasing power accounting and current value accounting are

155 ARS No. 6, supra note 4 , at 51 .

${ }^{156}$ Id. $51-52$.

${ }^{157}$ Hills, supra note 22 , at E-2.

${ }^{158}$ Obtaining increased tax depreciation allowances has been reported to be top legislative priority of "big business." Wall St. J., Oct. 22, 1975, at 1, col. 5. 
proposals with different objectives .... [R]eporting current values in financial statements will be considered in another project presently on the Board's agenda . ..."159 Yet, what are the different objectives of current value accounting? The preface to the FASB's proposal indicates that the real difference is that procedures for applying general price-level adjustments are already well-developed, while much research remains in the area of current value accounting. ${ }^{160}$ In other words, the importance is that a half step toward current value accounting can be taken now while the full step would be delayed some years. ${ }^{\mathbf{1 6 1}}$

Financial statements prepared under generally accepted accounting principles are intended to serve the common needs of diverse users, including present and potential shareholders and creditors. ${ }^{162}$ To the extent these needs diverge, the emphasis has been placed upon disclosure relevant to the current and prospective investors and lenders. ${ }^{163}$ Yet accounting in units of general purchasing power does little to assist shareholders or creditors, present or potential. The FASB's concern with immediate implementation of price-level accounting suggests a desire to use financial reporting to achieve immediate tax relief for business. Such politicization of financial reporting may introduce distortions contrary to the standards of disclosure under the federal securities laws.*

${ }^{159}$ FASB EXPosure Draft, supra note 2, $\{70$.

${ }^{160}$ Id. iii.

${ }^{161}$ Taking the half step could very well preclude the whole. The high costs of computer reprogramming, education and other expenses of adopting price-level accounting would effectively prohibit for some time a second conversion to replacement cost or current value accounting. See Burton, Financial Reporting in an Age of Inflation, $139 \mathrm{~J}$. Accountancy, Feb. 1975, at 68, 70.

${ }_{162}$ See APB Statement No. 4, supra note 38, 1125.

${ }^{163} \mathrm{Id}$.

* At press time the SEC adopted the proposal described in note 22 supra but limited it to businesses whose inventories plus gross property, plant, and equipment equal $\$ 100,000,000$ or more and ten percent or more of total assets. The SEC stated that it does not view this as competitive with the FASB proposals. SEC Accounting Series Release No. 190, 5 CCH FED. SEC. L. ReP. If 72,212 (Mar. 23, 1976) (adding rule 3-17 to regulation S-X); Staff Accounting Bulletin No. 7, 5 id. 74,166 . At the same time, the SEC proposed a safe harbor rule to deal with potential anti-fraud liability of persons determining current replacement costs pursuant to the new requirements. SEC Securities Act Release No. 5696, [Current] id. 9 80,406 (Mar. 23, 1976). 